IRSH 6I (2016), pp. 389-42 I doi:I0.10I7/S00208590I6000547

(C) 2016 Internationaal Instituut voor Sociale Geschiedenis

\title{
Can Peasants Make a Revolution? Colonialism, Labour, and Power Relations in Pierre Bourdieu's Algerian Inquiries*
}

\author{
ANDREA RAPINI \\ University of Modena and Reggio Emilia \\ Viale Allegri 9, 42 I2 I, Reggio Emilia, Italy \\ E-mail: andrea.rapini@unimore.it
}

Aвstract: This article analyses the Algerian inquiries of Pierre Bourdieu. It begins by retracing the most pervasive, medium- and long-term interventions of French colonial power in Algerian society: the introduction of capitalism and the internment of civilians in the centres de regroupement. Next, it outlines the social subjects studied by the young agrégé of philosophy and his representation of labour. Subsequent sections deal with shifts in the public stance of Bourdieu regarding the revolutionary propensity of these people. On this tricky testing ground, Bourdieu engaged with and critically confronted the ideas of Germaine Tillion and Frantz Fanon. His position is reviewed from a historical-philological approach in order to set the texts in their temporal and spatial contexts, establish parallels and/or divergences, and verify the effects such comparisons produced. The conclusions emphasize the richness and originality of Bourdieu's inquiries given the era in which they were made and highlight, in light of the recent global reorientation of labour history, some of the vital viewpoints expressed on the origins of capitalism in the colony.

\section{INTRODUCTION}

Pierre Bourdieu (1930-2002) arrived in Algeria at the end of 1955 to carry out his military service, having completed his studies in philosophy at the École normale supérieure in Paris a year earlier, gaining his agrégation. At this point in his life, he considered himself a philosopher; in fact, he was planning to prepare a doctoral thesis with Georges Canguilhem on the "temporal structures of emotional life".

After completing his military service, he remained in the French colony until near the end of 1959, experiencing a Faustian thirst for knowledge and a powerful attraction to the faces, environments, lifestyles, labour practices, economies, and mindsets of a population of which France, in his opinion,

\footnotetext{
* I would like to thank Pier Giorgio Ardeni and Michele Nani for their comments and suggestions on earlier versions of this article.
} 
knew little or nothing, despite I 20 years of colonial rule. ${ }^{\mathrm{I}}$ The peasants, who were the largest and most representative part of the population, were the focus of Bourdieu's interest. ${ }^{2}$ These people shared many of the characteristics of the rural population of his native area, Béarn, on the border between Spain and France, and Bourdieu clearly became aware of this himself some years later. ${ }^{3}$ Moreover, in that particular historical moment, peasants were at the heart of an international debate resonating within the French Left: who is the real revolutionary subject? The working class, according to the Soviet model that was open to dispute after 1956 , or the peasants, according to the increasingly accepted Chinese view? Bourdieu was sensitive to this and held many of the expectations and outlooks of the young leftist intellectuals of the École normale, ${ }^{4}$ although he did not share the communist positions of Althusser or Foucault (until 1952) and was more inclined towards libertarianism. ${ }^{5}$

His desire for knowledge as well as his sentimental involvement with the peasant population and his political commitment to those colonized, initially pushed Bourdieu towards a study of all the available publications at the library of the Gouvernement général in Algiers, where he drafted his first book on Algeria. ${ }^{6}$ Subsequently, the same elements drove him to take advantage of the fact that he was "on the ground" and thus able to listen, observe, record, and photograph the people first-hand, gaining completely original material for research. Thus, between 1958 and the early i 960 , Bourdieu carried out two extensive inquiries, which followed rhizomatic ramifications but which were completed at the request of the same institution, the ARDES. ${ }^{7}$ The first inquiry, Travail et travailleurs en Algérie, ${ }^{8}$ was conducted in eleven urban centres and four centres de regroupement, i.e. internment camps for the civilian population, set up by the French army

I. After his return to France, he would return to Algeria for a few months in 1960, and again in 1963 .

2. See "L’autre Bourdieu. Celui qui ne disait pas ce qu'il avait envie de cacher. Entretien réalisé par Hafid Adnani et Tassadit Yacine", Awal. Cahiers d'Études Berbères, 27-28 (2003), p. 235.

3. Franck Poupeau, "The Invention of the State: Bourdieu Between Bearn and Kabylia”, Berkeley Journal of Sociology, 59 (201 5), available at http://berkeleyjournal.org/201 5/I 2/the-invention-ofthe-state-bourdieu-between-bearn-and-kabylia/, last accessed is June 20I6; and Loïc Wacquant, "Following Pierre Bourdieu into the Field", Ethnography, 5:4 (2004), pp. 387-4I4.

4. Pierre Bourdieu, "Entre amis", Awal. Cahiers d'Études Berbères, 27-28 (2003), pp. 83-88.

5. Lucien Bianco, "On n'avait jamais vu le 'Monde'. Nous étions une petite frange de gauche entre les communistes et les socialistes”, Awal. Cahiers d'Études Berbères, 27-28 (2003), pp. 267-277.

6. Pierre Bourdieu, The Algerians, with a preface by Raymond Aron (Boston, MA, I962) [Sociologie de l'Algérie (Paris, 1958)]. On the changes made by Bourdieu to the various editions of this text, see Enrique Martin-Criado, Les deux Algéries de Pierre Bourdieu (Paris, 2008).

7. The Association de recherche sur le développement économique et social, funded by the Caisse de développement de l'Algérie, at the urging of several progressive civil servants of the Statistique Générale de l'Algérie, including the director Jacques Breil.

8. Pierre Bourdieu et al., Travail et travailleurs en Algérie (Paris, 1963). 
to cut off sources of supply to the National Liberation Front (Front de Libération Nationale - FLN). The second research project, published in Le déracinement in $1964,{ }^{9}$ involved peasants from centres de regroupement in rural areas.

Bourdieu, thus, entered Algeria as a budding philosopher and left, after an intense period of research against the backdrop of a colonial war (1954-1962), with an original scientific profile that spanned contrasting realms of knowledge. Already his work provided a foretaste of some of the concepts he would develop in the following decades. ${ }^{10}$ This is therefore a seminal period. Nevertheless, it remains perhaps the most obscure period in his biography; in fact, Bourdieu's works from these years, especially his inquiries, are among the least known, cited, and translated in the world. ${ }^{I I}$ The current inaccessibility of many sources helps to explain to some extent, though not completely, such a delay.

Bourdieu kept no diary while staying in Algeria, nor did he have any sort of journal describing the work he was carrying out or the material collected. In an interview with Franz Schultheis, he said that the conditions under which he was working were so extreme and his time so full that he was able only to jot down "messy notes". ${ }^{\mathrm{I} 2}$ It is currently impossible to verify the existence of or hypothesize with regard to the quantity of these notes, as the main repositories conserving the various parts of Bourdieu's archival legacy are closed to the public. ${ }^{13}$ Another source of information is the archive of Abdelmalek Sayad, one of his closest collaborators, co-author of Le déracinement, and subsequently an astute scholar of Algerian

9. Pierre Bourdieu and Abdelmalek Sayad, The Uprooting: The Crisis of Traditional Agriculture in Algeria (Cambridge 2010) [Le déracinement. La crise de l'agriculture traditionnelle en Algérie (Paris, 1964)].

Io. Gisèlle Sapiro, "Une liberté contrainte. La formation de la théorie de l'habitus”, and Tassadit Yacine, "Genèse de La Domination masculin", in Louis Pinto, Gisèle Sapiro, and Patrick Champagne (eds), Pierre Bourdieu, sociologue (Paris, 2004), pp. 49-78, 93-I I6; Enrique MartinCriado, "L'Algérie comme terrain d'apprentissage du jeune sociologue", in Frédéric Lebaron and Gérard Mauger (eds), Lectures de Bourdieu (Paris, 201 2), pp. 77-93. The continuity is evident in one of the works from the last decade of his life, The Weight of the World: Social Suffering in Contemporary Society (Stanford, CA, 2000 [1993]).

I I. Travail et travailleurs en Algérie has never been translated into English. Le déracinement was translated, but not until 2010 (The Uprooting). Philip S. Gorski, "Bourdieu as a Theorist of Change", in idem (ed.), Bourdieu and Historical Analysis (Durham, NC, and London, 2013), pp. I-I 5; Gisèlle Sapiro and Mauricio Bustamante, "Translation as a Measure of International Consecration: Mapping the World Distribution of Bourdieu’s Books in Translation”, Sociologica, 2-3 (2009), pp. I-45.

I 2. Pierre Bourdieu, "Seeing with the Lens: About Photography. Interview with Franz Schultheis", in Tassadit Yacine (ed.), Algerian Sketches (Cambridge, 2013 [2008]), p. 307.

I3. Physically, one part is housed in the Archives Nationales connected to the École des Hautes Études en Sciences Sociales, the other in the Collège de France. I applied for access during my period as visiting researcher at the ÉHÉSS in Paris in 2014-20I5. 
immigration in France. ${ }^{\mathrm{I}}$ However, since 20I 2, access has been provided to more than 329 folders of papers conserved at the Mediatheque of the Cité nationale de l'histoire de l'immigration in Paris ${ }^{15}$ thanks to the re-cataloguing that followed its initial opening in 2009. As regards the other people directly involved at the time, of three statisticians who contributed to the inquiries, Alain Darbel and Jean-Paul Rivet are now dead. The third, Claude Siebel, has contributed significant information in the form of both memoirs and further reflections; this material, however, needs to be backed up by a richer series of sources, especially as Siebel's arrival in Algeria dates from the end of 1959, when Bourdieu's inquiries were already at an advanced stage. ${ }^{16}$ Neither Siebel, nor I were able to consult the ARDES documents kept by the foundation of the Caisse de développement de l'Algérie at the Archives nationales d'Outre-mer, which houses much of the administrative documentation brought back to France after independence. ${ }^{17}$

At the same time, the search for other private archives that might provide information on Bourdieu has failed. The archive of Frantz Fanon, who was in Algeria at the same time and had a considerable influence - as discussed below - on the academic course of the young philosopher, contains no trace of direct or indirect contacts between the two. ${ }^{18}$ Lastly, François Maspero, Fanon's publisher, who had a dense network of acquaintances and international contacts among the anti-colonial left wing, unfortunately died on I I April 20 I 5 before I could interview him, and without leaving a public archive.

Given this situation, the following article is based on published sources and literature in the vast field of Bourdieu studies ${ }^{19}$ and concentrates on his Algerian inquiries as they are the least-known part of his academic output.

I4. Regarding Sayad, listen to Amín Pérez, "Une sociologie de la révolution coloniale. Abdelmalek Sayad et Pierre Bourdieu en Algérie”, Conférence-débat de l'UniverCité, Musée de l'histoire de l'immigration, 24 March 2015 , available at http://pierrebourdieuunhommage.blogspot. it/201 5/04/ecouter-amin-perez-une-sociologie-de-la.html, last accessed 27 October 2015.

I 5 . A preliminary inventory can be found at http://www.generiques.org/images/pdf/inventaires/ 48.pdf, last accessed 23 January 2016.

I6. Claude Seibel, "Les liens entre Pierre Bourdieu et les statisticiens à partir de son expérience algérienne", in Jacques Bouveresse and Daniel Roche (eds), La liberté par la connaissance. Pierre Bourdien (1930-2002) (Paris, 2004), p. 106; and Claude Seibel, Naissance d'un sociologue algérien. Abdelmalek Sayad et les enquêtes de l'ARDES (I958-I962), 8 ème rencontre autour de l'œuvre d'Abdelmalek Sayad, Oran, I 8 October 201 2, p. 4, available at http://www.if-algerie.com/oran/ linstitut/8-eme-rencontre-abdelmalek-sayad, last accessed 23 January 2016.

I7. The documents are "unclassified" and available at http://anom.archivesnationales.culture.gouv. fr/ark:/6I 56I/wz8 I 8jfdehf, last accessed I October 20I6. The archives defined as "de gestion" from certain state administrative sectors (health, labour, social security, etc.) remained in Algeria.

I 8. To be found at the Institut Mémoires de l'édition contemporaine (IMEC), where I consulted the Inventaire des archives Frantz Fanon at 174 rue de Rivoli, Paris, on 4 February 2015.

19. Marco Santoro, "Putting Bourdieu in the Global Field", Sociologica, 2 (2008), pp. I-32. 
More precisely, it examines them from the perspective of some of the nodes introduced into the international discussion by the global reorientation of historical studies. ${ }^{20}$ What do his inquiries tell us about the origins of capitalism, the market, and wage labour in the colony and, more generally, about the relationship between the Western model of development and a traditional society based on a different social structure and different cultural codes? Yet, a basic question remains at the heart of the matter and forms the main theme of this article, given that it was the doubt that dogged Bourdieu throughout those years and generated his original approach, combining academic study with politics: can the Algerian peasant make a revolution? And, if so, what revolution? And how could one answer such questions without a metaphysical approach, namely tracing the revolutionary consciousness back to its social conditions of possibility ? ${ }^{21}$

Starting from this perspective, the present article begins by retracing the most pervasive interventions of French colonial power in Algerian society - the introduction of capitalism and the internment of civilians in the centres de regroupement - to explain the reasons for and the object of the inquiries. Next, it outlines the social subjects studied by the young agrégé of philosophy and his representation of labour, emphasizing the richness and originality of Bourdieu's inquiries, given the era in which they were made, and highlighting some of the vital viewpoints expressed on the origins of capitalism in the colony.

The following sections deal with shifts in Bourdieu's stance regarding the revolutionary propensity of these people, especially the peasants. On this tricky testing ground, he engaged with and critically confronted the ideas of Germaine Tillion and Frantz Fanon. Through their works and statements, both of these intellectuals had a huge impact on the French-Algerian public debate $^{22}$ and on Bourdieu himself, who mentions them both explicitly and implicitly on several occasions. His thoughts on the revolution in Algeria, therefore, besides being the result of his own research, also developed

20. See Christian G. De Vito, "New Perspectives on Global Labour History: Introduction", Workers of the World. International Journal on Strikes and Social Conflict, I:3 (2013), pp. 7-3 I, available at https://workersoftheworldjournal.files.wordpress.com/20I4/10/workersof-the-world_-international-journal-on-strikes-and-social-volume- I-number-3.pdf, last accessed 29 September 2016 idem and Alex Lichtenstein, "Writing a Global History of Convict Labour", International Review of Social History, 58:2 (2013), pp. 285-325; Christian G. De Vito (ed.), Global Labour History. La storia del lavoro al tempo della "globalizzazione" (Verona, 2012); Marcel van der Linden, "Global Labour History: Provisional Results and Further Prospects", paper presented at the conference "Le travail pris dans le global: enjeux pour une histoire transnationale du travail", Paris, Conservatoire national des arts et métiers, 9 June 2015 (personal recording).

2 I. Pierre Bourdieu, Political Interventions: Social Science and Political Action, edited by Franck Poupeau and Thierry Discepolo (London, 2008 [2002]), p. xvi, and Abdelmalek Sayad, Histoire et recherche identitaire (Saint-Denis, 2002), p. 65.

22. James D. Le Sueur, Uncivil War: Intellectuals and Identity Politics during the Decolonization of Algeria, foreword by Pierre Bourdieu (Lincoln and London, 2005 [200I]). 
through his "for" and "against" views with regard to Tillion and Fanon, especially the writings of the latter on the peasants becoming the underclass. ${ }^{23}$ Despite this, the relationship between the three intellectuals has not yet been sufficiently examined. Consequently, the second part of this article attempts to objectify this relationship through a historical-philological approach in order to set the texts in their temporal and spatial contexts, establish parallels and/or divergences, and verify the effects such comparisons produced.

\section{SOCIAL VIVISECTION}

The destructuring of the traditional Algerian society and the agrarian reforms imposed by France are - explicitly or implicitly - the essential background to any Bourdieusian reasoning on colonialism, which he interprets as a "total social fact", following Balandier's i95 I seminal article on the "colonial situation". ${ }^{24}$ Without giving a brief summary, his inquiries would be incomprehensible.

When the French seized Algeria from the Ottoman empire in 1830 , the country's main means of subsistence was agriculture, including livestock farming. Such practices were linked intimately to a specific socioeconomic structure. No individual private property existed in Algeria, nor any legal concept of such. There were three types of land: the first belonged to the sovereign; then there was land possessed by the religious foundations; and, finally, land owned by the tribes, which had an indivisible and hereditary right to communal landownership and everything produced on that communally held land. The socio-legal organization revolved around the extended family, which was the alpha and omega of the whole system, in which the man, the head of the family, enjoyed a dominant role. Next were the tribes, which collected together several families linked by blood or by simple alliances. Finally, there was the village assembly. If disease did not strike the Algerians, there was a double balance, between technical and natural conditions - no more was required than what the land could give and between resources and population. The glue that held everything together was a constellation of values: the land itself, solidarity, gifts, subordination of the individual to the community, honour, and Islam. ${ }^{25}$

23. Frantz Fanon, The Wretched of the Earth, with a preface by Jean-Paul Sartre (New York, 2004 [I96I]).

24. Bourdieu, Sociologie de l'Algérie, p. iा7; Georges Balandier, "La situation coloniale. Approche théorique”, Cabiers internationaux de sociologie, II (I95I), pp. 44-79. To contextualize the concept of the "colonial situation" within colonial studies, see Frederick Cooper, Colonialism in Question: Theory, Knowledge, History (Berkeley, CA, [etc.], 2005), pp. 33-55.

25. Charles-André Julien, Histoire de l'Algérie contemporaine, vol. I, La conquête et les débuts de la colonisation I827-I87I (Paris, I964), p. 9. In addition to these classic texts, more recently: Emmanuel Blanchard and Sylvie Thénault, "Quel 'monde du contact'? Pour une histoire sociale 
Given these characteristics, we can understand how the agrarian issue became one of the objectives of colonization. France, not without casual errors and successes, achieved four interconnected results: land appropriation, the disclaiming of the rights of use accorded to tribes, the imposition of private property, and the emergence of a land market. These results were achieved by different means: blatantly violent, legislative, and administrative. ${ }^{26}$

Military intervention and the deposing of the sovereign allowed France to requisition the sovereign's lands. The French then seized those of the religious foundations, and finally they claimed rights to the remaining lands. With the excuse of wanting to ensure a living and working space for the tribes and to avoid conflicts over borders, the first restrictions were imposed, thus laying down the principle that an area of land equal to half or a quarter of the original area would suffice for the population's survival. Thus, between 1847 and I 863 , the peasants and farmers were uprooted from their ancestral settlements and "quartered" in smaller areas (cantonnements). ${ }^{27}$ The Sénatus-consulte of 1863 was the legal culmination of this slow bloodletting. The Warnier Law followed in I 873: under article 8 I 5 of the French Civil Code - "nothing can remain indivisible" - it removed common landownership within those areas that had already been severely shrunken and laid out the boundaries of small individual properties, contrasting the age-old local practices and a mentality that revolved around the community. ${ }^{28}$ These interventions were truly a vivisection of the society and caused far-reaching consequences that were to persist and later survived the revolution.

\section{THE THREE EFFECTS OF SOCIAL VIVISECTION}

In economic terms, there was an immediate transfer of the lushest, most fertile land from the hands of Algerians to those of the colonists and to European companies, which obtained the properties free or at low cost.

de l'Algérie pendant la période coloniale", Le Mouvement Social, 236:3 (201 I), pp. 3-7; Abderrahmane Bouchène et al. (eds), Histoire de l'Algérie à la période colonial, I830-1962 (Paris and Algiers, 20I2). On the different interpretations of "individual" and "community" outside Western Europe, see Prasannan Parthasarathi, "Agricultural Labor and Property: A Global and Comparative Perspective”, in Jan Lucassen (ed.), Global Labour History: A State of the Art (Bern, 2008), pp. $455-477$.

26. The jurists, for example, first "invent" the land categories based on the French legal model and then apply them to the present and pre-colonial Algerian past: Didier Guignard, "Les inventeurs de la tradition 'melk' et 'arch' en Algérie”, in Vanessa Guéno and Didier Guignard (eds), Les acteurs des transformations foncières autour de la Méditerranée an XIXe siècle (Paris, 2013), pp. 49-93.

27. Yves Lacoste, André Nouschi, and André Prenant, L'Algérie, passé et présent, le cadre et les étapes de la constitution de l'Algérie actuelle (Paris, I960), p. 3 I 4.

28. Charles-Robert Ageron, "Le nouveau régime foncier et le recul de la propriété indigène", in idem, Les algériens musulmans et la France (I87I-I9I9), 2 vols (Saint-Denis, 2005), I, pp. 67-102. 
The Algerian peasants were segregated in the areas that were most inaccessible and difficult to cultivate. ${ }^{29}$ Between I87I and 1919, in the Department of Algiers alone, where the most fertile plots were located (Mitidja Plain), the French settlers quadrupled their landownership, from ı 400,000 hectares. Between the two wars, ownership of land became increasingly concentrated due to the huge investment needed to modernize farms, techniques, and crops. Smallholdings tended to disappear. The only small farms remaining were among Algerians and these were in no way competitive with those of Western farmers and even struggled at subsistence level. On these lands, for example, between I 830 and 1950 the production of cereals decreased by 20 per cent compared with a doubling of the population. In I930, just over 26,000 Europeans possessed over 2,200,000 hectares of arable land. By 1950, the number of Europeans had decreased to 22,000 , but the area they owned had increased to 2,700,000 hectares, equivalent to eighty per cent of the land - producing about seventy per cent of Algeria's gross agricultural income. Conversely, the number of Algerian owners and sharecroppers diminished. The number of Algerian landowners dropped from 617,000 in 1930 to 494,500 in 1954 , while the number of sharecroppers fell from 634,600 to 60,400 in the same period. ${ }^{30}$

The social effects of this agrarian colonization were perhaps even more dramatic. What happened to the dispossessed peasants? What was the fate of the tribal communities and the consequences on attitudes, mindsets, and patterns of perception? Beyond the safety net provided by the village, forced to tackle arid lands and with few financial resources, the fate of the "quartered" population was impoverishment, misery, and often debt. Some succumbed immediately to the temptation to sell their land to the colonists. This meant that a mass of uprooted people began to migrate to urban centres in search of a new dignity to replace the loss of an identity focused around the land. In I 876, there were 82,976 Algerians in cities with over I0,000 inhabitants. By 1936, that figure had risen to 959,444. The percentage of rural dwellers now settled in towns rose from twenty-eight per cent to 44.6 per cent of the population. Internal migration and the expansion of the cities continued uninterrupted even after the war, and especially during the revolution as a result of military operations. Between 1954 and 1963 , the population of Algiers rose from I62,000 to 870,000 , that of Oran from I I 9,000 to 300,000. In Constantine, the figure increased from I03,000 to 275,000. ${ }^{3 \mathrm{I}}$ Most of the farmers expelled from their lands were destined to become part of the subproletariat in the urban centres. They had neither

29. André Nouschi, "Conclusion générale", in idem, Enquête sur le niveau de vie des populations rurales constantinoises de la conquête jusqu'en I919. Essai d'histoire économique et sociale (Paris, I961), pp. 740-749.

30. Benjamin Stora, Histoire de l'Algérie coloniale (I830-1954) (Paris, I99I), p. 48.

31. André Nouschi, L'Algérie amère (1914-1994) (Paris, I995), p. 202. 
the means, nor the mental attitude to become independent entrepreneurs and there was no economy present able to absorb them all as free wage labourers. Thus, from the I93os onwards, around all the medium and larger cities, a large belt of bidonvilles mushroomed. In the words of Algiers' Mayor Jacques Chevallier, "in 1938 the Muslim population living in the bidonville did not exceed 4,800 people, while there were I 25,000 , twenty-five times more, in 1953-1954". ${ }^{32}$ This explains why, following an inquiry carried out in the Massif region of Aurès in the I930s and then further data collection in the mid-I950s, the ethnographer Germaine Tillion coined the term clochardisation to describe the change that had occurred before her eyes. ${ }^{33}$

Lastly, the material catastrophe had cultural corollaries. Colonization grafted systems of thought and capitalist practices onto attitudes, patterns of perception, and lifestyles modelled around a supportive and antiindividualistic social structure. Time measured by economic value, wage labour, unemployment, credit, profit, private property, and the market were all categories imported from France. ${ }^{34}$ Naturally, this process involved several generations of Algerians. Nevertheless, the impact on the mindsets of the peasants produced large-scale uprooting. Caught between a shattered world and another installed with brutality, accompanied by the subversion of the previous symbolic order, the Algerians showed a range of reactions that went from outright rejection to frenetic adhesion. These two extremes were punctuated by a spectrum of intermediate behaviours, where the old ways persisted while being clearly influenced by the new. ${ }^{35}$

With the start of the war of independence (November 1955), Algeria suffered the blow of the centres de regroupement, which deepened the decomposition of the country's social structure and amplified its effects.

\section{THE CONCENTRATIONARY UNIVERSE}

The word regroupement covers various meanings, including "different types of settlements (camps, centres, villages) to which inhabitants of all areas declared inaccessible were transferred, and the movement of nomadic or sedentary populations that ensued". ${ }^{36}$ From November 1954, the French

\footnotetext{
32. Stora, Histoire de l'Algérie coloniale (I830-1954), p. I02.

33. Germaine Tillion, L'Algérie en 1957 (Paris, I957), p. 40.

34. Frederick Cooper, "African Labor History", in Lucassen, Global Labour History, p. I I 5.

35. Bourdieu showed an interest in the effects of colonialism on the mentality from his first works preceding his field research. See Pierre Bourdieu, "Disintegration and Distress", in idem, The Algerians, pp. I I9-I44; idem, "Le choc des civilisations", and idem, "La logique interne de la société algérienne traditionnelle”, in idem, Le sous-Développement en Algérie (Algiers, 1959), pp. 40-64.

36. Charles-Robert Ageron, "Une dimension de la guerre d'Algérie. Les 'regroupements' de populations", in Jean-Charles Jeauffret and Maurice Vaïsse (eds), Militaires et guérilla dans la guerre d'Algérie (Brussels, 200I), p. 327.
} 
army began "emptying" certain zones defined as "unsafe". The escalation of the conflict led to a decree on I7 March 1956 that established "zones where residency is regulated or prohibited, with the possible delegation of this power to the prefects and the military authorities". This decree legitimated practices that were already being enforced by the army and encouraged the authorities to clear territories that were identified as dangerous, moving not only men, women, and children, but also livestock. The houses were then gutted, burned, and, in many cases, their roofs were removed so that they could be monitored from the skies. There was a population exodus from the "prohibited zone". Initially, no preparations were made to receive these people, and their movements were completely disorganized. They were uprooted ruthlessly, and while some managed to save a few possessions, others lost everything.

After an initial phase of uncontrolled overcrowding, which persisted until I957, French authorities started to monitor the flow of these civilians and to decide where they were to be placed, partly in an attempt to avoid a public health disaster. Soon, however, the army took over from the civilian authorities and the centres began mushrooming beyond control and often quite unbeknown to the political authorities in Paris. ${ }^{37}$ The military considered these centres as one of the most effective weapons for fighting the guerrilla war. ${ }^{38}$

At the same time, however, the function of the centres became independent of the struggle against the FLN and took on its own ends: the resettlement was used to conduct a war on civilians, and to directly apply pressure on the inmates of the camps to get them to support France. By engendering the total dependence of the population on colonial rule, the centre became a dispositive that permitted the regulation, surveillance, and psychological conquest of the people, and enabled them to be punished as desired. ${ }^{39}$

Finally, the centre provided cheap labour for the colonists. The resettlements located at the edge of the economically lively areas (Algiers, Oran) were used as reservoirs of labour by private firms. Indeed, many colonist settlers pressed to have resettlements near their properties as this would afford them not only a workforce that was desperate, but also the discipline guaranteed by the military presence; thus, the centres served to entrench the establishment of the colonial order.

37. In official jargon the word "centre" is used for both the transfer to pre-existing settlements (recasement) and for collection in a confined area of a residential settlement (resserrement). Finally, the same concept comprises the actual regroupment centres specifically called "regroupements", in which the mass concentration of civilians was carried out outside residential areas and featured military-style buildings of huts and barracks that were built by the future inhabitants themselves. 38. Bourdieu and Sayad, Le déracinement, p. I I.

39. Michel Cornaton, Les camps de regroupement de la guerre d'Algérie (Paris, I998 [1967]), pp. $232-233$. 
It should be clarified that these centres de regroupement differed from the Nazi lagers both because labour was formally free and extermination was never an aim. However, mortality was extremely high, especially among children, due to malnutrition, insufficient health care, and the overall conditions of degradation. In I959, there were an estimated 500 child deaths per day. Thus, while the centres for Algerian civilians were not designed to be a "genocide factory", they did leave the human beings confined there people who had been deprived of citizenship by the Code d'Indigénat in I $88 \mathrm{I}^{40}$ - to sink into death. ${ }^{4 \mathrm{I}}$

Faced with this scenario, the delegate general of the French government, Paul Delouvrier, attempted to stop the proliferation of the resettlements by issuing a decree in March 1959 to block the creation of new centres without his authorization. The measure proved to be ineffective, given that by July 1960 the centres had more or less doubled in number, reaching a total of roughly $\mathrm{I}, 700.4^{42}$ Even in 196I, close to the ceasefire, the expansion continued. Every attempt to dismantle the camps failed until the war had actually ended, and even after Algerian independence many of the inmates were unable to leave as they had no place to go. The data relating to April I96I, provided by the commissionership for urgent action, speak for themselves, and yet they probably underestimated the numbers. The "Muslim" population in Algeria totalled 9,000,000; there were 2,392 centres; the "Muslim" population collected in all types of centre numbered I,958,302, almost twenty-two per cent of all Algerians labelled as "Muslims". If we consider that, in addition to these inmates, approximately $\mathrm{I}, \mathrm{I} 75,000$ peasants had abandoned their homes due to the war, the overall number of uprooted farm workers was roughly $3,525,000$, or fifty per cent of the rural population.

This extended concentrationary dispositive (see Figure I), common to European colonial history, ${ }^{43}$ accelerated the disintegration of traditional society. Although within the centres work remained predominantly free and the population were allowed to farm cultivated land, in practice the distance between such land and the centres often discouraged farmers from doing so.

40. Laure Blévis, "Les avatars de la citoyenneté en Algérie coloniale ou les paradoxes d'une catégorisation”, Droit et Société, 48 (2001), pp. 557-580.

4I. Joël Kotek and Pierre Rigoulot, Le siècle des camps. Détention, concentration, extermination. Cent ans de mal radical (Paris, 2000), pp. 599-606.

42. Sylvie Thénault, "Rappels historiques sur les camps de regroupement de la guerre d'Algérie", in Michel Rocard, Rapport sur les camps de regroupement et autres textes sur la guerre d'Algérie (Paris, 2003 [1959]), p. 234.

43. For comparative and diachronic research on the place of the labour camps in the context of the global history of oppression and exploitation in the early modern and modern world, see http:// socialhistory.org/nl/projects/labour-camps, last accessed I October 20I6. The focus is on penal transportation to and within the Dutch East Indies; early modern and modern prison workhouses in Hamburg; incarceration and internment in Italy and the Italian colonies; and the Tsarist katorga and Soviet gulags in Western Siberia. 


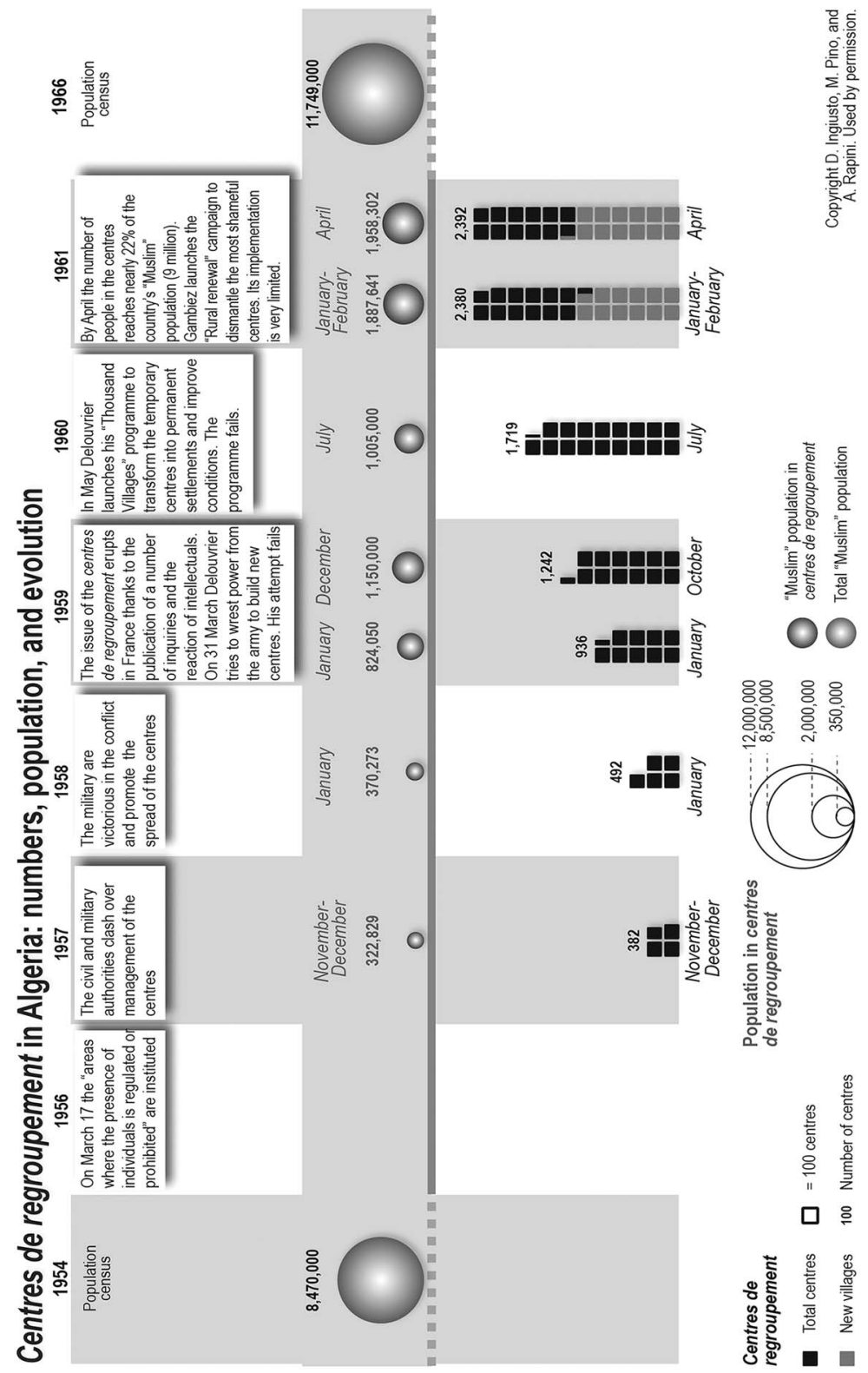

Figure I. Centres de regroupement in Algeria.

Sources: Ageron, "Une dimension de la guerre d'Algérie", pp. 359-36i; Cornaton, Les camps de regroupement de la guerre d'Algérie. 
Perhaps it is reasonable to question whether a clear distinction between free and unfree labour is indeed pertinent in such a context. ${ }^{44}$ There were two, possibly co-existing, alternatives for those who had abandoned or lost their lands: degradation and reliance on colonial aid alone, or the search for a paying job. Those who had a family and were pursued by the problem of feeding their dependants every day were especially willing to accept any job whatsoever. At the same time, this spread of wage labour both outside and within the centres as employees of the French authorities introduced an element of disintegration that was alien to the ethos of traditional society. Against the background of the colonial war, the majority of labour was temporary and precarious, often meted out on a daily basis.

The effects of the social vivisection inflicted on Algeria, the disastrous unfolding of the war, and the pressure of French public opinion following the revelations surrounding the centres de regrompement ${ }^{45}$ induced the colonial authorities to promote two large inquiries under the auspices of the ARDES.

\section{WHO WERE THE WORKERS IN THE COLONIAL SITUATION?}

In collaboration with a group of statisticians who were responsible for the quantitative section, the first inquiry was carried out on a representative sample of the entire population. ${ }^{46}$ The choice of the object clearly indicates the breadth of research: the work was considered a key observation point to document the conflict between "traditional models" and "models imported and imposed" by colonization, or, if you will, between "rationalization imperatives" and "cultural traditions". ${ }^{47}$ From this point of view, Travail et travailleurs en Algérie presented an "Esquisse pour un tableau des classes sociales", in which Bourdieu roughly outlines five broad groups with different internal structures. ${ }^{48}$ On the one hand, the "Esquisse" underlines a

44. Even if there is no case study on Algeria, regarding the important debate about free and unfree labour see Tom Brass and Marcel van der Linden (eds), Free and Unfree Labour: The Debate Continues (New York, 1997).

45. On the scandal created in France by the centres de regroupement, see Rocard, Rapport sur le camps de regroupement, pp. I03-I 53. On torture, see Raphaëlle Branche, La torture et l'armée pendant la guerre d'Algérie (1954-1962) (Paris, 2001).

46. Bourdieu worked on a sub-sample ten times smaller than that identified by the statisticians to represent the whole population: 190 heads of family.

47. Bourdieu et al., Travail et travailleurs en Algérie, p. 266.

48. The subproletariat: non-permanent workers with no qualifications and often no education (unemployed and daily workers, small traders and artisans, employees of small commercial and business enterprises, unskilled workers with no qualifications); the proletariat: manual workers, skilled and permanent workers in the modern sector; craftspeople and traders; the petty bourgeoisie: permanent non-manual workers in the modern sector (petty officials, bureaucrats, accountants, employees in the public or private sector); the modern bourgeoisie: administrative managers, managers in private business, professions, teaching staff). 
certain essentialism in defining social classes. In fact, Bourdieu himself would review this approach critically about fifteen years later when, in dialogue with Edward Thompson ${ }^{49}$ - among others - he provided an innovative and anti-essentialist approach to the understanding of social classes. ${ }^{\circ}$ This is confirmed by the removal of the Tableau when the Travail et travailleurs en Algérie was republished under the title Algérie $60^{5 \mathrm{I}}$ in 1977 in the early stages of a period of intense review of classifications, nomenclatures, and reflexivity in the social sciences. On the other hand, however, the "Esquisse" is highly rich in its representation of work, not strictly linked to wage labour alone. Within this framework, for example, the self-employed feature in their own right and not as an anomaly. ${ }^{52}$ There are, moreover, many grey areas that Bourdieu identifies as workers shifting between unemployment, daily and precarious employment, odd jobs, and the trading of anything that the most deprived groups could manage to scrape together to allow them to survive physically and above all to gain self-respect, as Figure 2 shows. According to the imperatives of the traditional ethos - as one interviewee commented - "a worthy man, who does not want to be maintained by others, must work, even if this means accepting whatever comes along". 53

Within this cross section of the entire Algerian society, the most important "clivage sociale" is not that between free and unfree labour, but rather between "permanent workers" and "intermittent workers" (the unemployed, daily workers, small traders). Considering that the unemployed accounted for forty-three per cent of the workforce (people over fourteen years), the scope of this cleavage is evident. ${ }^{54}$ Furthermore, these figures, far from being a legacy of the previous society that was destined to be reabsorbed, were actually the effect of the process of imposing a capitalist society. Indeed, this group consisted overall of the dispossessed peasants who had migrated to the cities and become "clochardisés". Against the colonial narratives, and indeed

49. Bourdieu published Thompson in his journal in precisely this period: Edward P. Thompson, "Modes de domination et révolutions en Angleterre", Actes de la recherche en sciences sociales, 2:2 (1976), pp. I33-15 I.

50. Pierre Bourdieu, Distinction: A Social Critique of the Judgement of Taste (London 1984 [1979]). See also Philippe Coulangeon and Julien Duval, "Introduction", in idem (eds), The Routledge Companion to Bourdieu's Distinction (London and New York, 2015), pp. 6-8.

51. Pierre Bourdieu, Algeria 1960: Essays (Cambridge, 1979 [1977]).

52. Wage labour never appears as "true work". See Willem van Schendel, "Stretching Labour Historiography: Ideas from South Asia”, in Rana P. Behal and Marcel van der Linden (eds), Coolies, Capital, and Colonialism: Studies in Indian Labour History. International Review of Social History Supplement I 4 (Cambridge, 2007), pp. 229-26r.

53. Bourdieu et al., Travail et travailleurs en Algérie, p. 300 . On the concept of grey areas, see Marcel van der Linden, "Who are the Workers?", in idem, Workers of the World: Essays Toward a Global Labour History (Leiden and Boston, MA, 2008), pp. 17-37.

54. Bourdieu et al., Travail et travailleurs en Algérie, p. 268. 


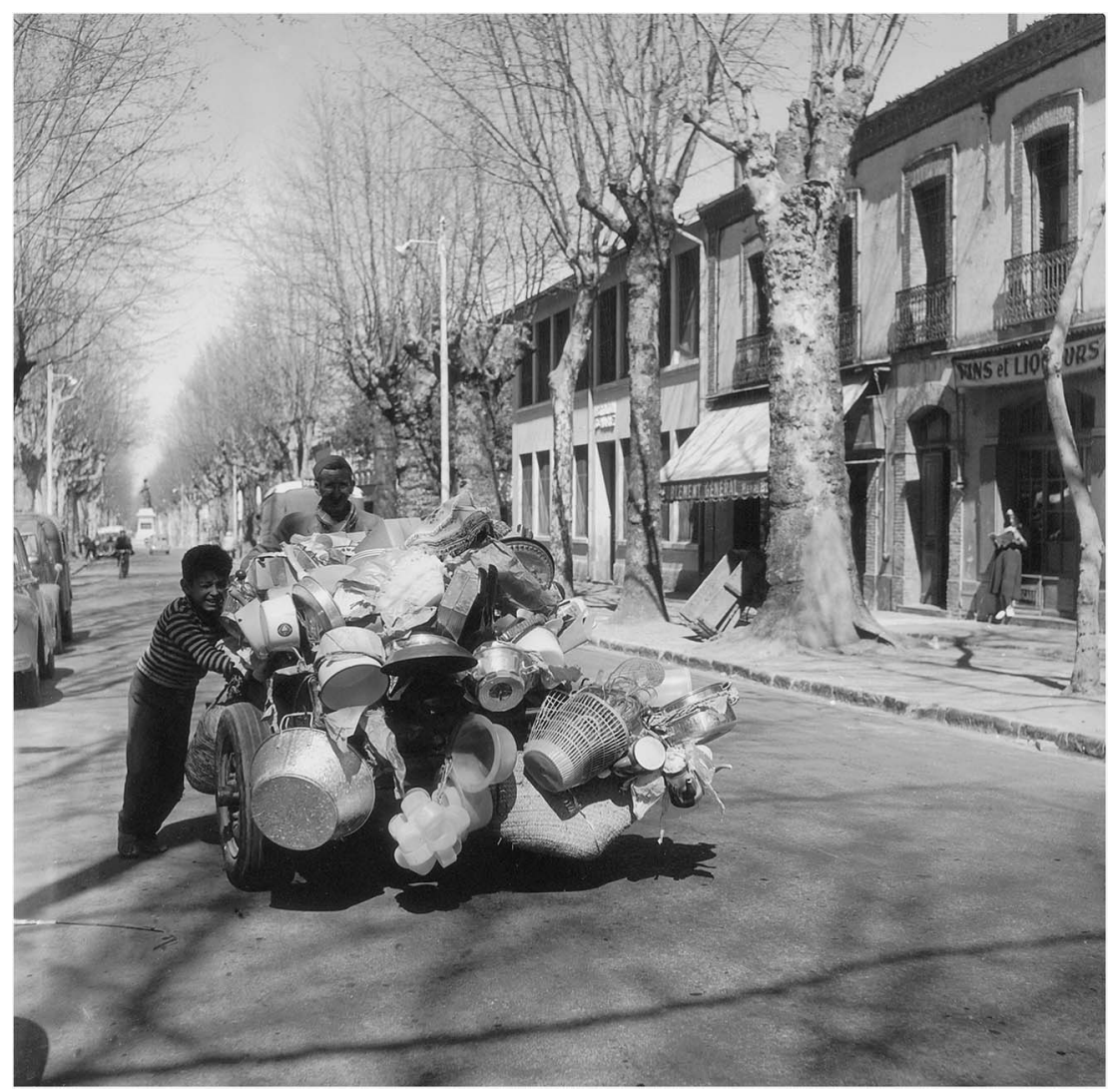

Figure 2. Pierre Bourdieu, a traveling merchant with his son, Orléansville, Chlef, RI4.

From: In Algeria. Testimonies of Uprooting, 1957-1961. (C) Pierre Bourdieu/Fondation Pierre Bourdieu, St. Gall. Courtesy: Photographic archive Pierre Bourdieu, Camera Austria, Graz.

the anti-colonial progressive narratives that supported a vision of the positive outcomes of the French presence in Algeria, Bourdieu was careful to recognize the damage arising from an inoculation of capitalism; "unemployment and intermittent work", he wrote, "prepare a disorganization of conduct which we must be careful not to mistake for innovation". 55

The inquiry's findings dealt with conduct and its link to the control of time and predictions for the future: permanent workers, who possessed material and cultural resources and career prospects, were able to develop a life plan based on a "rationalist ethos" and on a reasonably accessible future. On the other hand, the unemployed and precarious workers faced with no 
prospects in a job they despised were geared to satisfying "immediate needs" and remain trapped in the circle of the present or at most projected towards a utopian or mythical future. ${ }^{56}$

While wage labour was not the only measure of work, it was, nevertheless, considered by Bourdieu as a powerful element of disruption to the equilibrium of rural society. This function is particularly evident in the second inquiry into the peasants who had been uprooted and interned in the centres de regroupement. On this occasion, Bourdieu, in collaboration with Abdelmalek Sayad, developed a reasoning behind peasants' self-perception as workers. Although there are differences between areas where capitalist relationships are most prevalent (Collo) and those where they are less so (Chélif), the interpretation of sources was the same: the direct or indirect experience of wage labour reflexively led to criticism of the rural world. While peasants in traditional society felt themselves employed throughout the day for the whole year, they were unaware of the word "unemployment" and had no concept of a monetary calculation for labour. Once the relationship between work and monetary remuneration had been apprised, anything lying outside a relationship of "employment" became devalued. The "discovery of labour" as connected to a wage simultaneously caused the discovery of unemployment. Hence, any type of occupation - keeping watch in the fields or guarding the cattle, which was generally the responsibility of the elderly - that had previously had meaning within the context of a coherent social system now appeared not to be work, or even, in the absence of any monetary payment, to be a sort of "veiled unemployment". 57

What kind of job was preferred by the peasants interviewed? For the younger ones, especially, the greatest aspiration was stable wage labour, even if this required moving away from the centre de regroupement, migrating, and running the risk of "clochardisation". Thus, within the centres the depeasantization of Algerians that had begun with the colonial intervention continued, not only as a result of the physical detachment from the land, but also due to a mental detachment from traditional peasant culture.

\section{PLACING THE INQUIRIES WITHIN THE CONTEXT OF GLOBAL LABOUR STUDIES}

On closer inspection, the social vivisection imposed on Algeria by France is actually a specific form of "primitive accumulation". 58 In a Marxian sense, it

56. Ibid., pp. 31 2, 367 .

57. Bourdieu and Sayad, Le déracinement, pp. 74, 77-79, 8I. Evidencing the close links between the two inquiries, the same considerations can be found in Bourdieu et al., Travail et travailleurs en Algérie, p. 287.

58. On temporal successions, see Werner Bonefeld (ed.), Subverting the Present: Imagining the Future (New York, 2008). On recent uses and transformations of the notion of primitive 
is the founding historical experience of capitalism through the separation between workforce and means of production. ${ }^{59}$ Bourdieu never used the expression primitive accumulation. However, although he preferred the approach of Weber and Sombart to the Marxist lexicon, ${ }^{60}$ he was fully aware that this process was exactly what he was describing. What, then, does his analysis tells us in this regard?

Far from what happened in Europe being mechanically replicated in the colony, as might be in line with a linear and progressive conception of history, ${ }^{61}$ Bourdieu highlighted the asymmetries while taking into account his own mental categories; these had been formed in the West and could unconsciously lead to a transfer of "the patterns of experience of industrialized societies" instead of understanding "events and men in their irreducible originality". ${ }^{62}$

Given that the timescale required to change a mindset is different from that required to change economic structures, the inquiries brought to light a discrepancy in Algeria between the behaviour patterns forged by the moral order of traditional society and the new capitalist configuration. Of course, this also happened to a lesser extent at the origins of capitalism. However, in North Africa - Bourdieu explained - the phenomenon was macroscopic as it was linked to the particular historical mode of violent dispossession. He thus found that, more than one hundred years after the beginning of the "assimilation" of Algeria, behaviours and attitudes not "in tune" with the new economic system persisted. Beyond the ways in which things were done and existed, the affirmation of these capitalist "economic structures" continued alongside those of traditional society, engendering a layering of diverse temporalities that was

accumulation, see Jim Glassman, "Primitive Accumulation, Accumulation by Dispossession, Accumulation by 'Extra-Economic' Means", Progress in Human Geography, 30:5 (2006), pp. 608-625.

59. "Primitive" is intended as "original", which better translates the ursprünglich as used by Marx. On this concept, see Werner Bonefeld, "Accumulazione primitiva e accumulazione capitalistica. Categorie economiche e costituzione sociale”, in Devi Sacchetto and Massimiliano Tomba (eds), La lunga accumulazione originaria. Politica e lavoro nel mercato mondiale (Verona, 2008), pp. 89-105, and Werner Bonefeld, "History and Social Constitution: Primitive Accumulation is Not Primitive”, The Commoner, March 2002, available at http://commoner. org.uk/debbonefeldor.pdf, last accessed 9 January 20 I6.

60. In the 1950s, he also formed his political identity in opposition to the kind of dominant Marxism then prevailing: Pierre Bourdieu, Sketch for a Self-Analysis (Cambridge, 2007) [Esquisse pour une auto-analyse (Paris, 2004)].

6r. See Massimiliano Tomba, "Layered Historiography: Re-Reading the So-Called Primitive Accumulation", in Idem, Marx's Temporalities (Leiden, 2013), pp. I 59-186.

62. Bourdieu et al., Travail et travailleurs en Algérie, p. 265. Bourdieu explicitly criticizes the oriental colonialist incrustations that at that time - before Edward W. Said, Orientalism (New York, 1979) - became part of a field of university studies on the East. See also Zachary Lockman, "Reflections on Labor and Working-Class History in the Middle East and North Africa", in Lucassen, Global Labour History, p. I 2 I. 
particularly evident in the plurality of labour relations, of which wage labour was just one. Research, therefore, is alien to the point of proposing a "teleology of modern wage labour", destined to spread wage earning throughout the whole society after its introduction with capitalism, and thus to squeeze out the acceptance of other forms of employment being represented as labour, reinforcing the dichotomous contrast between modern wage labour and traditional work. This dichotomy was evident in earlier positions. ${ }^{63}$

Although the affirmation of capitalism occurred primarily through military intervention, it cannot be reduced to the mere act of violence and its coercive dimension. ${ }^{64}$ The picture painted by Bourdieu is nuanced. The range of reactions recorded in his inquiries, displayed not only a retreat to tradition ("traditionalism of despair") as a form of rejection, ${ }^{65}$ but also a whole spectrum of adhesion, especially among the sectors of society that had been most drastically uprooted and among those who had most heavily suffered the effects of the concentrationary universe. Bourdieu thus highlighted the productive dimension of the spread of capitalism. He understood its ability to produce consensus even in a colonial situation, where explicit force blatantly outweighs the simple mechanism of accumulation and anonymous control of labour.

Overall, was this a residual scenario destined to be integrally reabsorbed and to render the Algerian economic and social landscape the same as that of France? Rather, Bourdieu described a certain possibility that remained open, which he summed up with the term "creative reinvention" to concisely render the events underway, thus distancing the fate of the French colony from any preconceived outcome. ${ }^{66}$ While the I950s saw the successful spread of stadial theories, both in the realms of sociology of modernization and Marxism, which, however, considered the present as belonging to the West and the future to the Rest, one of Bourdieu's most original aspects was his avoidance of any stadial or determinist leanings in the relationship between the West and the colony. ${ }^{67}$ For example, his works

63. Fabien Sacriste, "Une lecture de la crise de l'emploi en Algérie coloniale. L'opposition entre travail traditionnel et travail salarié dans l'œuvre algérienne de Pierre Bourdieu”, in Maxime Quijoux (ed.), Bourdieu et le travail (Rennes, 201 5), pp. 97-I I 2.

64. The concept of "accumulation by dispossession" focuses too greatly on coercion: David Harvey, "Accumulation by Dispossession", in idem, The New Imperialism (Oxford, 2003), pp. I $37-182$.

65. Regarding this concept, see Pierre Bourdieu, "La société traditionnelle. Attitude à l'égard du temps et conduite économique", Sociologie du travail, I (1963), pp. 30-3 I; Bourdieu et al., Travail et travailleurs en Algérie, p. 357; Bourdieu and Sayad, Le déracinement, p. 68.

66. Bourdieu et al., Travail et travailleurs en Algérie, p. 3 I4.

67. For a Marxist critique of Western ethnocentricity, see Dipesh Chakrabarty, Rethinking Working Class History: Bengal I 890-1940 (Delhi, I989). Regarding the eurocentrism of labour studies, see Jan Lucassen, "Outlines of a History of Labour”, IISH Research Paper 5 I (2013), p. 20, available at https://socialhistory.org/sites/default/files/docs/publications/respaps I.pdf, last accessed 9 February 2016, and Marcel van der Linden, "Enjeux pour une histoire mondiale du travail”, Le mouvement social, 24I (I9I 2), pp. 4-5. 
of this period contain no concept of any progress proposed by the West to the colonies, although this view was highly fashionable at the time. ${ }^{68}$

Research results at a historical and socio-anthropological level attribute to Bourdieu a belief that the knowledge he had gained meant he felt equipped to judge the chances of the Algerian revolution in a more realistic way than any political ideology that was removed from an in-depth analysis of the relationships of domination. However, far from being linear, his considerations on the revolution were the outcome of a circuitous course whose genealogy necessarily involved a comparison with the ideas of Frantz Fanon and Germaine Tillion.

\section{FANON AGAINST BOURDIEU?}

Both men - Bourdieu and Fanon - were in Algeria between I955 and I957, although they almost certainly never met. ${ }^{69}$ Fanon arrived in the French colony in 1954 after his graduation in neuropsychiatry in Lyon, having accepted a position at the hospital of Blida, near Algiers. Bourdieu was to take a series of photographs in the same place between 1959 and $1960 .^{70}$ Fanon's desire to create a non-oppressive approach to psychiatry at Blida was shattered by the reality of colonialism: if psychiatry should serve to free men from the chains of madness, in a colonial situation this is impossible to achieve unless we remove the main cause of estrangement: colonial rule itself. ${ }^{7 \mathrm{I}}$ Fired by this belief, Fanon established and strengthened his contacts with the FLN. This led to his expulsion from the hospital, and from Algeria, at the end of 1956. At the beginning of 1957, he moved to Tunis, where he began his militancy in the FLN, which had established its political headquarters there. By this time, Bourdieu had been in Algiers for a number of months. While practising medicine, Fanon also continued his political activity by writing first for the paper Résistance Algérienne and then later for the official organ of the FLN: El Moudjabid. Fanon met Raymond Aron at Tunis in 1957 after the publication of the latter's La tragédie algérienne, in which the sociologist affirmed his support for Algerian independence. ${ }^{72}$ It was Aron who offered

68. Of the same opinion: Julian Go, "Decolonizing Bourdieu: Colonial and Postcolonial Theory in Pierre Bourdieu's Early Works", Sociological Theory, 31:I (2013), pp. 49-74.

69. There is no trace of a meeting between the two men in either of the two biographies written on Fanon: David Macey, Frantz Fanon: A Biography (New York, 2000), and Alice Cherki, Frantz Fanon: A Portrait (Ithaca, NY, 2006 [2000]). No academic biography of Bourdieu has yet been published.

70. Pierre Bourdieu, Picturing Algeria, edited by Franz Schultheis and Christine Frisinghelli, with a foreword by Craig Calhoun (New York, 2012 [2003]).

7I. Frantz Fanon, "Letter to the Resident Minister", in idem, Toward the African Revolution (New York, 1994 [1964]), pp. 52-54.

72. The pamphlet was published in 1957 by the Parisian publishing house Plon. 
Bourdieu the post of assistant lecturer at the Sorbonne in 1960; he also signed the preface to the English edition of Sociologie de l'Algérie. ${ }^{73}$

Fanon and Bourdieu were two French intellectuals taking a public stand against the colonial war at this time, and their position created quite a stir, especially among the pieds-noirs. Their stance was to influence the course of both their lives, although Bourdieu was not at the time the charismatic public figure he would become after the I980s and Fanon had not yet been assigned the role of "bible of the decolonization movement" ${ }^{74}$ as would happen following the publication of Les Damnés de la Terre and his early death in 196..$^{75}$

Born in 1907 in Allègre (Haute-Loire), while at university, Germaine Tillion studied ethnology under one of this discipline's most eminent scholars, Marcel Mauss. In 1934, she was awarded a scholarship to study the Berber peasant population in the Aurès, in southern Algeria. Tillion carried out research in the field until I940. On her return to France, she opposed the Nazi invasion and joined the Resistance, but was captured two years later and deported to the Ravensbrück concentration camp. At the end of the war, she became an activist with the Association nationale des Anciennes déportées et internées de la Résistance (ADIR), collecting evidence and conducting research on the resistance and on deportation.

Following the outbreak of the Algerian uprising in November 1954, she returned to Algeria thanks to the Centre national de la recherche scientifique (CNRS), which was called upon by the French authorities to study the colony. She spent a total of a year and a half there, partly in the Aurès region and partly in Algiers. While in Algeria, moved by a genuine desire for reform, she agreed to collaborate with the Governor-General Jacques Soustelle. ${ }^{76}$ This decision attracted much criticism and vitriolic attack..$^{77}$

By June 1956, she had returned to Paris. At the urging of the ADIR, which was very keen to communicate information on Algeria, she published a long article entitled L'Algérie en 1956 in the September issue of the journal Voix et Visages. To increase its dissemination, the ADIR decided to print $\mathrm{I}, 500$ copies in the form of a small volume that was distributed

73. Bourdieu, The Algerians, pp. v-vii.

74. Stuart Hall, "The After-Life of Frantz Fanon: Why Fanon? Why Now? Why Black Skin, White Masks?", in Alan Read (ed.), The Fact of Blackness: Frantz Fanon and Visual Representation (Seattle, WA, 1996), pp. I 2-37.

75. Fanon, The Wretched of the Earth.

76. She was responsible for setting up the social centres for the education of children: Germaine Tillion, "I centri sociali", in idem, Alla ricerca del vero e del giusto. Dalla Shoab all'Algeria, una testimone del male del Novecento, edited by Tzvetan Todorov (Milan, 2006 [200I]), pp. 209-2 I 9. 77. Simone de Beauvoir, for example, writes in her diary La forces des choses in 1963 of a dinner with friends (Bost and Lanzmann) during which “they rip to shreds" Tillion's article that had been published in L'Express, 28 August to 3 September (1958), under the title "Témoignage remis à la justice militaire française" - on the trial of the FLN leader Saadi Yacef. The dinner guests call the article "une vraie saloperie" (absolute rubbish) (Italian edition (Turin, I966), p. 420). 
directly through its network of militants. As this publication actually came out at the very beginning of the following year, it was entitled L'Algérie en 1957. Thanks to the high public profile of the author and the ADIR's network of relations, the text had a profound resonance in the politically active sectors of both France and Algeria, circulating in the "spongy sectors" of Algeria and reaching the FLN. In fact, Tillion was actually contacted more than once by Saadi Yacef, leader of the autonomous zone of Algiers during the battle of 1957 . According to the anthropologist's own account, their first meeting started with a discussion of the arguments set out in L'Algérie en $1957 .{ }^{78}$ Given the reception it received, the publishing house Minuit chose to bring out a second edition of the book in June of the same year. ${ }^{79}$ Le Monde discussed the publication on its front page on I I June. ${ }^{8 \circ}$

L'Algérie en 1957 described the impoverishment of the peasants of the Aurès and the state of "underdevelopment" prevailing in the country as a result of social and economic change. The causes of this poverty were to be traced back to the "contact" between a "modern economy" and an "archaic" society and the inability of the latter to become more dynamic or modern due to its closure to outside influences. ${ }^{8 \mathrm{I}}$ Therefore, according to Tillion, it followed that democratic France was duty bound to remain in Algeria to bring about reform and create the conditions necessary for the country's modernization. A further consequence was the "absolute necessity" for the Algerian economy to function in symbiosis with the French economy, as an "unlimited and unconditional" independence would expose the country to "extreme danger". ${ }^{2}$

The renown of the book, but simultaneously its condemnation by both French and Algerian intellectuals in favour of independence, increased due to public praise from one of the most famous pieds-noirs. Born in the village of Mondovi in I9I 3 to a French worker and a Spanish domestic help, Albert Camus was supported through his youth thanks to the hard, menial work of

78. Germaine Tillion, "Témoignage remis à la justice militaire française", in idem, Les Ennemis complémentaires. Guerre d'Algérie (Paris, 2005 [1960]), pp. 257-272. See also Donald Reid, "Re-viewing The Battle of Algiers with Germaine Tillion", History Workshop Journal, 60: I (2005), pp. 93-II5, I04, I05, 108.

79. Germaine Tillion, “Introduction", in idem, L'Afrique bascule vers l'avenir (Paris, 196 I [1960]), pp. I 8-19. The re-edition of L'Algérie en 1957 was published under this title, with further commentaries.

80. Anne Fernier (pen name of Anne de Seynes, editor of the ADIR publications), "Introduction", in Tillion, L'Algérie en I957, p. 8. Later, Tillion became a researcher at the École Pratique des Haute Études. In her volume Les Ennemis complémentaires she speaks out against the "two terrorisms": both the Algerian and the French.

8I. Paul A. Silverstein and Jane E. Goodman, "Introduction: Bourdieu in Algeria”, in Jane E. Goodman and Paul A. Silverstein (eds), Bourdien in Algeria: Colonial Politics, Ethnographic Practices, Theoretical Developments (Lincoln and London, 2009), pp. I 5-16, 53.

82. Tillion, "Témoignage remis à la justice militaire française”, pp. 261, 263. 
his mother, who was widowed in I9I4. He had a French education in French Algeria, and even after his move to France in 1940 his relatives remained in Algeria. The start of the terrorist attacks by the FLN against French (and Algerian) civilians generated questions of life and death that were more than idealistic. The statement Camus made when he dramatically distanced himself from the use of terrorist violence by the FLN while collecting his Nobel Prize in Stockholm in December 1957 should be considered within this biographical perspective: "I believe in justice, but I will defend my mother before justice". This statement unleashed furious controversy. ${ }^{83}$ At this delicate juncture, Camus met with Tillion several times both in Algeria and in France between 1956 and 1957 and remained in contact with her until his death in $1960 .{ }^{84}$ They shared the same basic ideas on the future prospects of Algeria and which were the correct means to use, thus considering the aspects of a revolution. As regards the first issue, while condemning colonial oppression Camus opposed national independence for various reasons. In addition to a wish to safeguard the pieds-noirs, he feared that if his country were to be left to itself by France it would plunge headlong into poverty and be attracted to the growing "Muslim imperialism" of which he had glimpsed some signs in the Arab world. ${ }^{85}$ Moreover, he did not believe there was an Algerian nation; in his opinion the Jews, Turks, Greeks, Italians, and Berbers would have had just as much right as Arabs to reclaim the leadership of this nation. ${ }^{86}$ His reasoning led him to propose a federal solution that could hold together the various intertwined communities in Algeria and France. ${ }^{87}$ As regards the second issue, which was closely related to the first, the question regarding the revolution and the most appropriate social subjects to embody it completely lost interest and realism. He held steadfast, however, to his moral condemnation of both the torture and to terrorism, which Camus completely ruled out from any ideal of revolution. ${ }^{88}$ The views shared with

83. Albert Camus, "The Nobel Prize Press Conference Incident, December 14-17, 1957", in idem, Algerian Chronicles (Cambridge, MA, 2013 [1958]), pp. 2 I 3-2 I6. See also Le Sueur, Uncivil War, pp. Iо9-i I7.

84. Albert Camus, "Carnets", I October 1957, in idem, Oewvres complètes, vol. IV, 1957-1959 (Paris, 2008), pp. I $265-\mathrm{I} 266$.

85. Camus considered the signs coming from Egypt as dangerous for the "West".

86. According to Edward Said, Camus considered the presence of the French in Algeria as "an essence subject to neither time nor interpretation", or as "the only story worth being narrated". "The difference in attitude and tone" is marked in Bourdieu's Sociologie de l'Algérie: Edward W. Said, Culture and Imperialism (New York, I994), pp. I79-180.

87. Camus' reference is Marc Lauriol, a law professor in Algiers.

88. Camus summarizes his position in a collection of interventions: Algerian Chronicles and in particular in "Algeria 1958" [Algérie en 1958"] in a clear reference to the title of Tillion's book, pp. 387-394. Algérie en 1957 is described by Camus as "that admirable book by Germaine Tillion", p. 389. In fact, she was to support her friend in the period when many misunderstood him: Germaine Tillion, “Albert Camus et l’Algérie”, Prenves, 91 (1958), pp. 69-72. 
Tillion are evident, and in fact he wrote the introduction to the American edition of her L'Algérie en 1957, defining it as the only "true, fair and constructive" account. $^{89}$

In 1957, just after the publication of the first two editions of Tillion's book, Fanon published a series of articles criticizing the European "sociologists" and "Islamologists", whom he considered guilty of being unable to comprehend the colonial world. ${ }^{9 \circ}$ Although Tillion (and Camus) was never actually mentioned, the popularity of the author and the acclaim the work had received both in Algeria and France mean that it is reasonable to assume she was one of the main targets. ${ }^{9 \mathrm{I}}$ It is impossible that Bourdieu was the one under fire, as at that point in his career he was not a sociologist and had not yet published his study nor finished his inquiries.

At the end of 1957, Fanon returned to the same theme: "Les intellectuels et les démocrates français devant la révolution algérienne". ${ }^{92}$ Once again, there is a strong indication that writers such as Germaine Tillion are being targeted when he rails against those who limit themselves to condemning only the "excesses" of the French, together with those of the FLN, while avoiding a condemnation of the very presence of France, which they regard as a reforming and modernizing force. ${ }^{33}$ This stance was based on blindness in the face of the "truth" regarding colonialism: "every Frenchman in Algeria has a relationship with the native people that is based on force". ${ }^{94}$

\section{BOURDIEU WITH FANON}

In the second half of 1959 , Fanon published L'an $V$ de la révolution algérienne. ${ }^{95}$ It is a clearly political book, containing a compilation of a number of essays that had previously appeared separately. The aim of the

89. Germaine Tillion, Algeria: The Realities (New York, 1958). The quotation is taken from Augustin Barbara, "Germaine Tillion”, in Jeanyves Guérin (ed.), Dictionnaire Albert Camus (Paris, 2009), p. 890.

90. See Frantz Fanon, (no title), Résistance Algérienne, i6 May 1957.

91. Evidencing the importance of L'Algérie en 1957 in that context, Bourdieu himself discusses it critically in Sociologie d'Algérie. Fanon, too, was certainly familiar with L'Algérie en 1957 as it reproduces a letter to the publisher Maspero in which Fanon refers to the various editions of that volume: letter from Fanon to Maspero, Tunis, 25 July 196I, in Frantz Fanon, Écrits sur l'aliénation et la liberté, edited by Jean Khalfa and Robert Young (Paris, 20I 5), pp. 56I-562.

92. This is the title of three articles that appeared in El Moudjabid on I, I 5 , and 30 December.

93. Frantz Fanon, "French Intellectuals and Democrats and the Algerian Revolution", in idem, Toward the African Revolution, pp. 76-90. When she met with Saadi Yacef, Tillion tried to make him commit to avoiding actions against civilians.

94. Fanon, "French Intellectuals and Democrats and the Algerian Revolution", pp. 89-90.

95. The volume came out in Cabiers libres, 3, published by Maspero. In I96I, the publisher reissued the book under the title Sociologie d'une révolution despite the reservations of Fanon, who did not consider himself a sociologist as he did not accept the dominant models of that science. English translation: A Dying Colonialism (New York, I994 [1965]). 
volume is threefold. Firstly, to describe the unravelling of the relations of dominion provoked by the revolutionary mobilization. Secondly, to recount the formation of an Algerian nation through struggle, which Fanon referred to as the "revolutionary pedagogy of nation-building", and which was not, therefore, linked to any supposedly unalterable, essentialist identity. Lastly, given that Fanon was writing as a militant actively engaged in the cause being described, he aimed to use the public debate to weaken colonial dominance by discussing the social and mental advancement triggered by the uprising.

Bearing in mind this threefold perspective, Fanon's observation of women had a paradigmatic function because it illustrated their emancipation both in relation to deference to the foreign colonial power and towards the men of their own culture, which was indisputably centred on male domination. At the basis of everything is the participation in the revolutionary process, and all share in the destiny of the new Algeria that will emerge. ${ }^{96}$

The passage that most strongly criticized the French sociologists appeared in the Appendix and reproduced the article that had originally appeared on I6 May 1957 in "Résistance algérienne". ${ }^{97}$ Hence, that article had actually been conceived and written before Bourdieu's Sociologie de l'Algérie appeared. This circumstance would make it difficult to maintain that there was a distinct contrast between Fanon and Bourdieu in this period, as argued by Robert Young, for example..$^{8}$

Furthermore, if we consider the effects of Fanon's public stance, we will have to recognize his undoubtable influence on the development of Bourdieu, who read the psychiatrist's writings carefully, as evidenced by notes on the book found by Amin Perez in Abdelmalek Sayad's archive in Paris. ${ }^{99}$ When $L$ 'an $V$ de la révolution algérienne came out, the two young intellectuals certainly held greatly differing views of the actions of the FLN. Although Bourdieu acknowledged the FLN's political role, he gave voice to a certain uneasiness, while Fanon remained close to Abane Ramdane right up until his death in December 1957. The two men differed also due to the links between Fanon's theories and Sartre's philosophy of freedom, while Bourdieu had been critical of this approach from the time he had been a student at the École normale supérieure.

96. See Fanon, A Dying Colonialism, pp. 35-67.

97. Fanon, "Appendix", in idem, A Dying Colonialism, pp. 64-66.

98. Robert J.C. Young, "Poetica del mutamento culturale radicale", in Frantz Fanon, Scritti politici. L'anno V della rivoluzione algerina, 2 vols (Rome, 2007), II, pp. IO-I I (Italian translation of $A$ Dying Colonialism). The afterword by Nigel Gibson is more balanced: "Non più in cielo. L'anno V della rivoluzione algerina cinquant'anni dopo", in ibid., pp. I 57-186. See also Nigel C. Gibson, Fanon: The Postcolonial Imagination (Cambridge, 2003).

99. I would like to thank Amin Perez for sharing the results of his Ph.D. dissertation: "Rendre le social plus politique. Guerre coloniale, immigration et pratiques sociologiques d'Abdelmalek Sayad et de Pierre Bourdieu" (Ph.D., École des Hautes Études en Sciences Sociales, 2015). The thesis will be published by Les Éditions Raisons d'Agir. 
Nevertheless, they did have certain points in common. Both were favourable to Algerian independence. Furthermore, they both felt a deep dissatisfaction with the "scientific" studies of colonialism, especially the ethnological studies; they used the concept of the "colonial situation" to indicate a power relationship of total domination. In addition, both intellectuals focused their approach on the habits of daily life and the symbolic dimension these have; they were both sensitive to the cleavages produced in society by the uprising. ${ }^{100}$ In this regard, the passages of $L$ 'an $V$ de la révolution algérienne describing the "clever tricks" of the veil and Western goods are surprisingly in line with the writings of Bourdieu in the early I960s. ${ }^{\text {IOI }}$

In two important writings, "Guerre et mutation sociale en Algérie" 102 and "Révolution dans la révolution", ${ }^{103}$ Bourdieu came close to Fanon's thesis. A large portion of these articles - which are very similar - is dedicated to the cleavages caused by the revolutionary war in the power relations both between the French and the Algerians and, within Algerian society itself, between men and women, between the young and the old, and between fathers and sons. The same subjects that were described by Fanon also reappear in Bourdieu's writings: the veil, the radio, school, and healthcare. See, for example, Bourdieu's photograph in Figure 3, taken in Algeria during the war. ${ }^{104}$ Bourdieu's conclusion is actually very close to Fanon's revolutionary tension and expresses a passionate adherence not only to the national revolution, but, above all, to the prospect of social change that was described at this stage as though it had already come about. This passage is illustrative:

[...] war is, itself, a language, it lends a voice to the people and a voice that says no [...]. In place of the shame we once glimpsed in certain people, we now find pride, and a shame at having been ashamed [...]. From their closed and secret world,

ı०0. Michael Burawoy, "Fanon Meets Bourdieu”, in idem and Karl van Holt, Conversations with Bourdieu: The Johannesburg Moment (Johannesburg, 201 2), pp. 74-90. This convergence is also highlighted by Jens Kastner, "Koloniale Klassifikationen. Zur Genese postkolonialer Sozialtheorie im kolonialen Algerien bei Frantz Fanon und Pierre Bourdieu", in Sophia Prinz et al. (eds), Pierre Bourdieu und die Kulturwissenschaften. Zur Aktualität eines undisziplinierten Denkens (Konstanz, 201 I), pp. 277-302.

ıог. On "clever tricks", see Michel de Certeau, "Faire avec: usages et tactiques", in idem, L'invention du quotidien. I. Arts de faire (Paris, I990 [1980]), pp. 50-68.

102. Études Méditerranéennes, 7 (1960), pp. $25-37$.

103. Esprit, I January 1961, pp. 27-40, in Bourdieu, Algerian Sketches, pp. 92-103.

104. Just one year after the publication of Le déracinement, Bourdieu devotes an entire volume, the result of a collective research, to the practice of photography: Bourdieu et al., Un art moyen. Essai sur les usages sociaux de la Photographie (Paris, 1965). Its reflections expand along a rugged thread of continuity with the Algerian experience, as can be seen, for example, on p. 2I, where Bourdieu comments on the "magical hopes" of the Algerian underclass, leading them back "to the objective truth of their condition" by employing the concept of class habitus. 


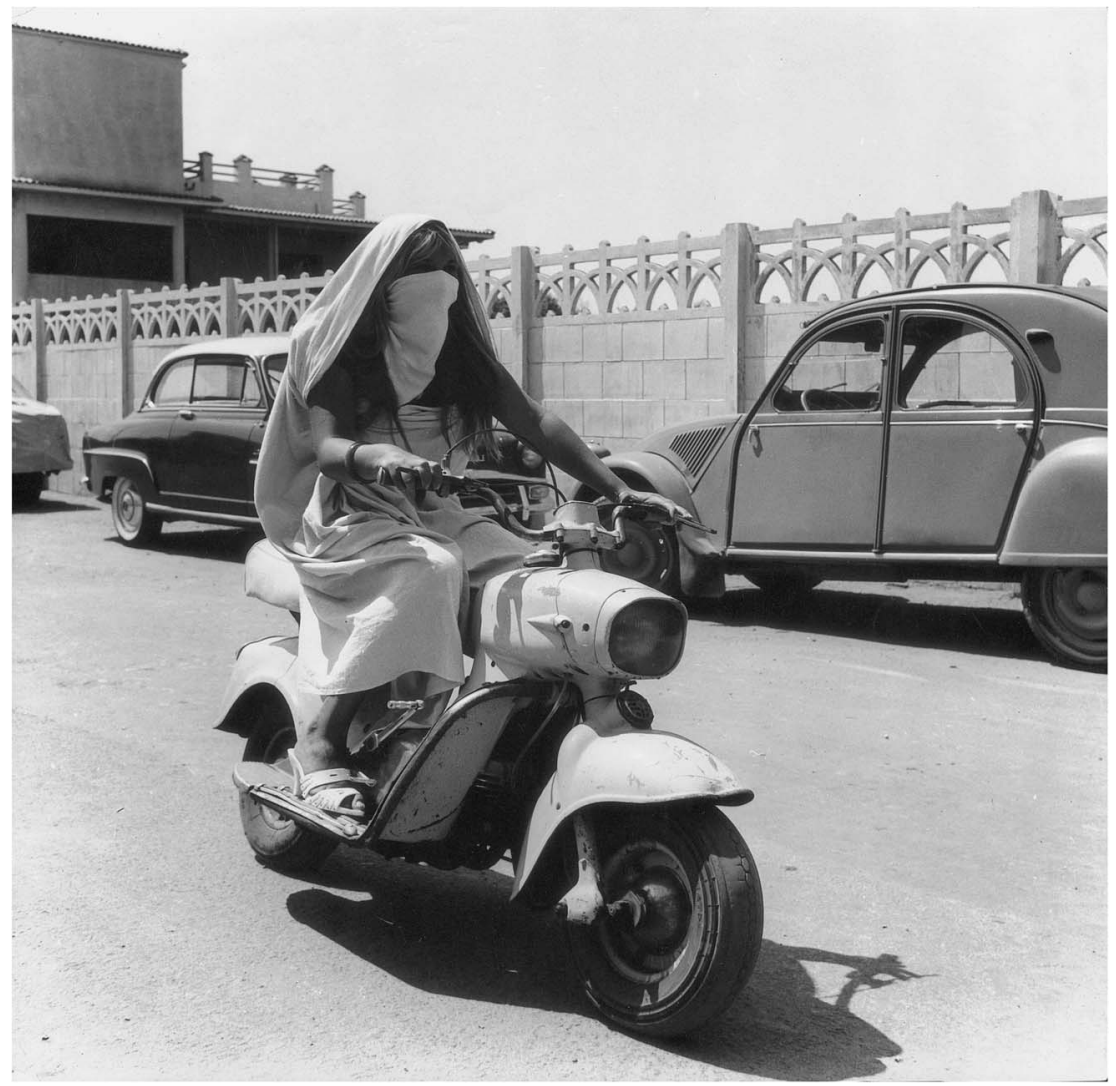

Figure 3. Pierre Bourdieu, Untitled, R I.

From: In Algeria. Testimonies of Uprooting, 1957-1961. () Pierre Bourdieu/Fondation Pierre Bourdieu, St. Gall. Courtesy: Photographic archive Pierre Bourdieu, Camera Austria, Graz.

[women] burst into the open space once reserved for men [...]. We can hope that when peace returns we will discover a completely different Algeria from the Algeria that saw the start of this war, an Algeria that is profoundly revolutionary because it has been revolutionized. ${ }^{\text {105 }}$

However, the distance between the positions of Bourdieu and Fanon was to become evident only in $196 \mathrm{I}$.

I05. Pierre Bourdieu, "Révolution dans la révolution", Esprit, 291:ı (i96I), pp. 27-40, in Bourdieu, Algerian Sketches, pp. 97, 98, 100, 103. My translation of the original edition. 


\section{THE PEASANTS: FORCE OF THE REVOLUTION AND NOT ... REVOLUTIONARY FORCE}

Before he died prematurely of leukaemia in December 196I, Fanon provided Maspero with a dictation of his last work: Les Damnés de la Terre. The book is an ideal extension of the previous one, and was published with a famous preface by Sartre. While $L$ 'an $V$ de la révolution algérienne talks of the molecular change produced in Algerian society by the struggle for freedom, Les Damnés de la Terre identifies the way in which the colonial system may be undermined, and by whom, as well as the means for advancing the struggle for a socialist political system. The means is violence. ${ }^{\mathrm{I}}{ }^{6}$ The actor will be someone who has nothing to lose but his shackles, and while, according to Fanon, the workers, artisans, and traders are all urban classes that profit from the colonial economic system and identify with the nationalist parties that call for reform, compromise, and "assimilation", "in colonial countries only the peasant class is revolutionary". ${ }^{107}$ The need for decolonialization to triumph would drive this group to besiege the towns, where an ally would be found in the lumpenproletariat, made up of the peasant fringe that had been uprooted from the countryside in the previous decades. ${ }^{108}$

In I961, Bourdieu, who had left Algeria between the end of I959 and early 1960, was teaching in the Faculty of Arts in Lille. During that summer, he returned to Algeria to carry out further interviews. It is quite plausible that up to then, given the conditions in which his inquires were carried out, the complexity of his methods (which involved statistical data, interviews, participant observation, and photographs), and the fact that he was continuously on the move, Bourdieu had not found the time to process all his data or extract the essence of their significance. The new stance on the Algerian issue, "De la guerre révolutionnaire à la révolution" ${ }^{109}$ was a first embryonic presentation of his theme of habitus and is particularly significant as all his publications up to 1964 , centred on his inquiries between 1958 and 1960, develop along the same lines. In fact, the original edition of the text hinted at an evolution of his ideas that would appear later in Travail et travailleurs en Algérie. ${ }^{\text {Iо }}$

I06. Edward Said, "Travelling Theory Reconsidered", in Robert Polhemus and Roger Henkle (eds), Critical Reconstructions: The Relationship of Fiction and Life (Stanford, CA, 1994), pp. $25 \mathrm{I}-267$.

107. Fanon, The Wretched of the Earth, p. 23.

108. Ibid., p. 8 I.

ı09. Pierre Bourdieu, "De la guerre révolutionnaire à la révolution", in François Perroux (ed.), L'Algérie de demain (Paris, I962), pp. 5-13. The book was legally deposited in the second half of 1962 .

I Io. Note I, in Bourdieu, "De la guerre révolutionnaire à la révolution", p. 9. The same volume also contains an anticipation of the statistical data reported in Travail et travailleurs en Algérie: A. Darbel and J.-P. Rivet, "Emploi et développement en Algérie", in Perroux, L'Algérie de demain, pp. 69-93. This article was written in April 1962. 
We may hypothesize that Bourdieu started processing his data in I96I, or early the following year, while his position with reference to Fanon's book had matured by the first half of 1962 . In the article, Bourdieu explicitly uses for the first time material from the "inquiries carried out between 1958 and

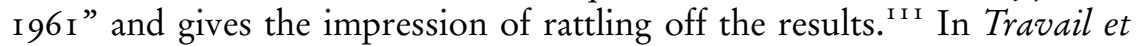
travailleurs en Algérie he repeats an earlier statement that would seem to be a direct reaction to Les Damnés de la Terre: "force of the revolution, the peasant world is not a revolutionary force in the true sense of the word". ${ }^{\text {I } 2}$ The same conclusion applies to the subproletariat. Bourdieu's arguments hint at the outlines of a theory of domination that he would go on to refine over the years: social subjects that are imprisoned in a condition of life that is characterized by "insecurity" and "incoherence" generally have an "uncertain" and "incoherent" vision of this condition. Conversely, the proletariat, which enjoys economic and social stability, shows a rational vision of the world that may be considered a precondition for the formation of a "rational revolutionary consciousness". ${ }^{113}$

This is a kind of reversal of Fanon's thesis, which is never explicitly mentioned. Yet, Bourdieu also believes at this point in time that the possibility of a "révolution dans la révolution" is still a reality. Nevertheless, he argues that the "radicalism of sentiment" should be combined with a "revolutionary radicalism", stemming from a realistic analysis of the circumstances and therefore unfettered by "the myth of the revolutionary revolution". ${ }^{\text {I } 4}$

When Bourdieu prepared the material for the two publications entirely dedicated to his inquires - Travail et travailleurs en Algérie and Le déracinement - his tone was darker. In the first work, he reuses the passages cited from "De la guerre révolutionnaire à la révolution", though this time he felt the need to name Fanon explicitly, leaving no room for ambiguity. ${ }^{\text {II }}$

Figure 4 offers a synthesis of Bourdieu's trajectory in Algeria.

\section{REVOLT VERSUS REVOLUTION}

I have argued that, in the wake of sentimental, civic, and political reasoning, Bourdieu committed to studying the various forms of work to measure the effects of the forced introduction of capitalism into traditional society in Algeria. Through two major inquiries he painted a rich and sophisticated picture of the attitudes of the colonial population in regard to work, to the

I I I. Bourdieu, "De la guerre révolutionnaire à la révolution”, p. 6.

I I 2. Ibid., p. 8. The sentence is repeated in Bourdieu et al., Travail et travailleurs en Algérie, p. 3 I 2 .

I I 3 . Bourdieu, "De la guerre révolutionnaire à la révolution”, p. 8.

I 4 . Ibid., p. 5 .

I I 5 . Note 2, in Bourdieu et al., Travail et travailleurs en Algérie, p. 3 I 2. 


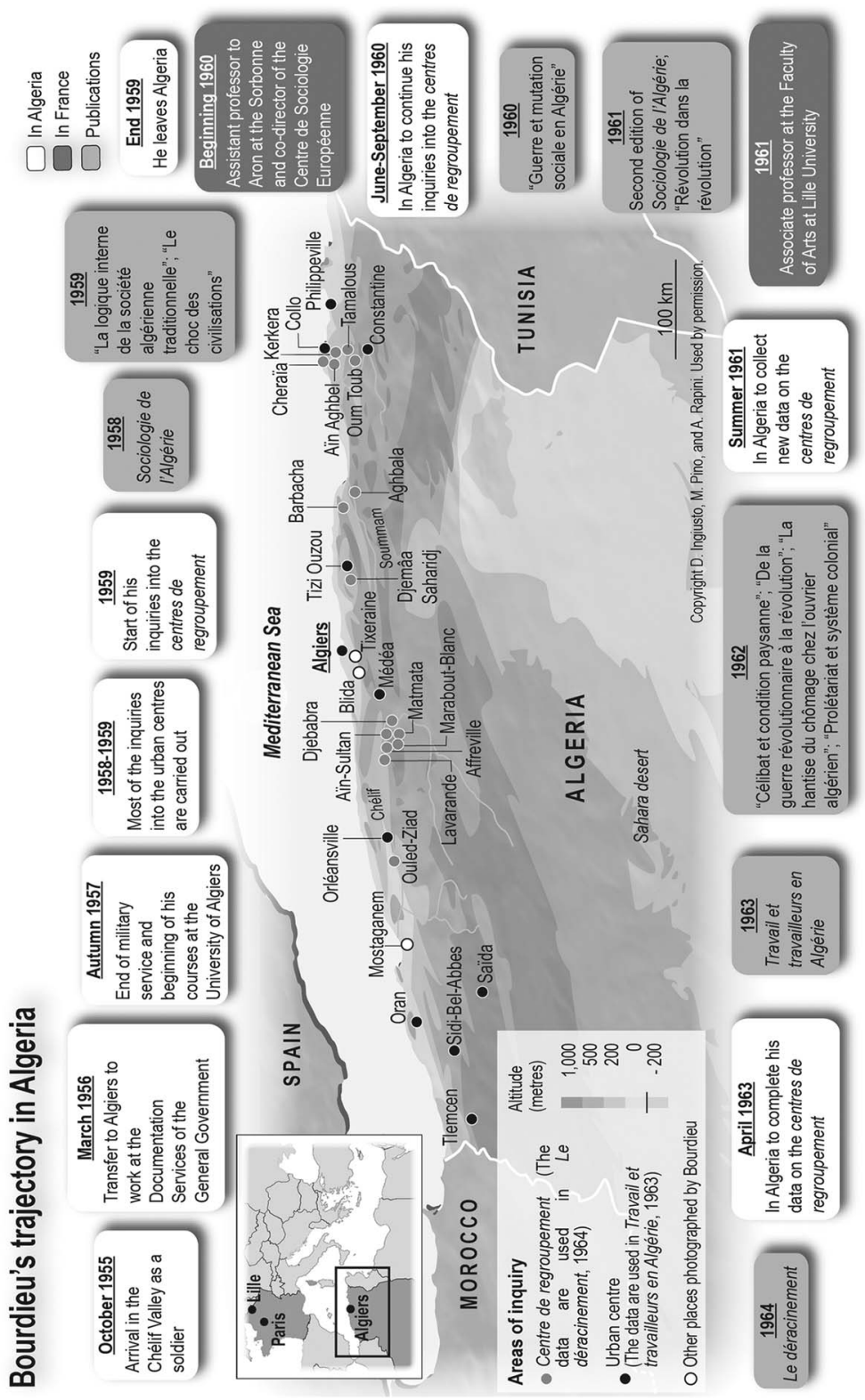

Figure 4. Bourdieu's trajectory in Algeria.

Sources: Bourdieu et al., Travail et travailleurs en Algérie; Bourdieu and Sayad, Le déracinement; Bourdieu, Sketch for a Self-Analysis; Awal. Cabiers d'Études Berbères, 27-28 (2003); Bourdieu, "Seconez un peu vos structures!", in Jacques Dubois, Pascal Durand, and Yves Winkin (eds), Le symbolique et le social. La réception internationale de la pensée de Pierre Bourdien (Liège, 2005), pp. 325-342; Bourdieu, Algerian Sketches. 
world, to time, and to the future. As the population was predominantly agrarian, the peasants were perforce at the centre of his analysis. At the same time, however, his specific interest in the peasants was the result of the spread of an international political discourse that, on the basis of the experience in China, saw them as the revolutionary subject par excellence. Distancing himself from an approach he considered to be abstract, Bourdieu regards his inquiry, which was exceedingly original and pushed well beyond the borders of academic disciplines of the time, as the most suitable instrument for dealing with a political problem in a scientific way: the formation of the social conditions of access to revolutionary consciousness. Only in this way - he believed - can one judge the chances of a rupture of relationships of domination within Algerian society that might accompany decolonization.

In this light, he approached with enthusiasm the texts of Frantz Fanon, whose basic thesis regarding the "revolution" under way in Algeria he shared until I96r. At the same time, he rejected both the underestimation of colonialism and the perspective of a realignment between France and Algeria proposed by Tillion and Camus, who he never actually names. Subsequently, he moved away from Fanon due to the interaction of several factors. Undeniably, he was to an extent disillusioned by the management of the postcolonial phase by the revolutionary elites, an approach that had immediately raised concerns about the country's future. At the same time, the theses on the uprooted peasants that appeared in The Wretched of the Earth are strident with the data of the inquiry that Bourdieu had not integrally interpreted until this time. Bourdieu's shift is also undoubtedly influenced by Sartre's famous preface, which Bourdieu had been developing "against" even while still studying at the École normale supérieure in Paris. In the early 1960s, the young sociologist judged Sartre wrong in his approval of the irresponsible speech by Fanon, as it was based on a lack of knowledge of the society. ${ }^{116}$

Finally, it is plausible that the international success of Fanon's theses, that had become a sort of Bible of Third Worldism, and the proposal of an Algerian paradigm within the global Left, had prompted Bourdieu to distance himself more strongly. ${ }^{17}$ Hence, in his texts of 1963 and I964, devoted to the processing of the vast masses of data he had produced, Bourdieu describes the peasants as a subject that does indeed take part in the national revolution and is prone to revolt, yet is incapable of either leading a social revolution or setting itself up as a ruling class in an independent Algeria. This holds at least if the concept of revolution is taken to be, as in this case, the ability to conceive the future on the basis of a lucid awareness

I 16. Bourdieu, "Entre amis", p. 85.

I 17. Jeffrey James Byrne, Mecca of Revolution: Algeria, Decolonization, and the Third World $\operatorname{Order}$ (New York, 2016). When Bourdieu republished the material from this inquiry in Algérie 6o, Third Worldism had exhausted its cycle and any explicit polemic reference to Fanon was removed from the text. 
of the mechanisms of reproduction of everyday life and social order in the present. For such an occurrence, then, voluntarism, the collective fervour, and simple thirst for justice of Algerian peasants cannot be sufficient. Instead sociological conditions are required that envisage the "likelihood" that it is possible to move beyond the present, and in which certain forwardlooking mindsets can be perceived. By contrast, the interviews and statistical data collected reveal that a combination of economic misery and cultural poverty made the Algerian peasants prisoners of the past, of the present, or of a magical and millenarian future. ${ }^{118}$

However central the problem of the revolution remains, around and beyond this issue Bourdieu's inquiries can also be interpreted as a sophisticated historical anthropology of labour that should be considered within its temporal, geographical, and cultural context. ${ }^{I 19}$ Labour in itself? Far from it. In fact, his research provides a contribution to the understanding of the historicity of labour that, by denaturalizing capitalism, demonstrates the resistible genesis of its specific wage form in a different context, outside Europe's heart. Bourdieu debunks the myth of the autopoiesis of the labour market that would have been incomprehensible in Algeria without the pervasive intervention of the French state that created the conditions necessary for its existence. ${ }^{120}$ Subsequently, as though in a circle, the study of the colony led Bourdieu to return critically to "conditions of existence and functioning" of capitalism in Europe. Here - he wrote - mistakenly assuming the universality of the category homo economicus, is concealed its genesis, connected to particular economic and social conditions, ${ }^{\mathrm{I} 2 \mathrm{I}}$ and it is assumed that the Western model of capitalism can be abstractly extended in the colony. ${ }^{\mathrm{I} 22}$ The same circular motion has been proposed in recent years by global labour history as it has returned to reconsider the prevailing approach of the later i950s. For this reason, Bourdieu's contribution is useful also to reinterpret the cultural assumptions of labour history and remove the Eurocentric overlay in the current period of European "provincialization". ${ }^{23}$

I 18. Bourdieu et al., Travail et travailleurs en Algérie, pp. 308-3 I .

I 19. Claude Didry, "Bourdieu et l'idée de travail'. Les enjeux de l'anamnèse algérienne pour une autre histoire sociale", in Quijoux, Bourdien et le travail, pp. I I $3-130$.

I 20. Note the agreement with Polanyi that Bourdieu would quote in the future, considering him to be illuminating. For example, Pierre Bourdieu, The Social Structures of the Economy (Cambridge, 2005 [2000]), pp. I, 224, and idem, On the State: Lectures at the Collège de France, 1989-1992 (Cambridge, 2014 [201 2]), pp. 7I, 75, 20I, 225, 245.

I 2 I. Bourdieu et al., Travail et travailleurs en Algérie, p. 3 I6.

I 22. Marcel van der Linden, "Refuting Labour History's Occidentalism", in Arvind N. Das and M. van der Linden (eds), Work and Social Change in Asia: Essays in Honour of Jan Breman (Delhi, 2003), pp. 249-26I.

I23. Van der Linden, Workers of the World, pp. 39-40. 


\section{TRANSLATED ABSTRACTS \\ FRENCH - GERMAN - SPANISH}

Andrea Rapini. Les paysans peuvent-ils faire la révolution? Le colonialisme, les travailleurs et les relations de pouvoir dans les enquêtes algériennes de Pierre Bourdieu.

Cet article analyse les études algériennes de Pierre Bourdieu. Il commence par retracer les interventions les plus répandues à moyen et à long terme de la puissance française coloniale en Algérie: l'introduction du capitalisme et l'internement de civils dans les centres de regroupement. L'auteur analyse ensuite les sujets sociaux que le jeune agrégé de philosophie étudie et la représentation qu'il fait des travailleurs. Les parties suivantes portent sur les changements dans la position publique de Bourdieu concernant la propension des travailleurs à faire la révolution. Sur ce terrain d'essai délicat, Bourdieu examine les idées de Germaine Tillion et de Frantz Fanon, en les abordant dans une perspective critique. Sa position est étudiée selon une approche historicophilosophique pour replacer les textes dans leur cadre temporel et spatial, établir des parallèles et/ou des divergences et vérifier les effets que ces comparaisons produisent. Les conclusions soulignent la richesse et l'originalité des recherches de Bourdieu pour l'époque à laquelle elles furent faites et mettent en valeur, à la lumière de la récente réorientation globale d'histoire du travail, certains points de vue essentiels qui y sont exprimés sur les origines du capitalisme dans la colonie.

Traduction: Christine Plard

Andrea Rapini. Können Bauern eine Revolution machen? Kolonialismus, Arbeiterklasse und Machtverbältnisse in Pierre Bourdieus Untersuchungen zu Algerien.

Dieser Beitrag analysiert Pierre Bourdieus Untersuchungen zu Algerien. Einleitend werden die tiefgreifendsten mittel- und kurzfristigen Interventionen der französischen Kolonialmacht in die algerische Gesellschaft rekonstruiert: die Einführung des Kapitalismus und die Inhaftierung von Zivilisten in den centres de regroupement. Anschließend werden die sozialen Subjekte skizziert, die der junge agrégé in der Philosophie untersuchte, ebenso seine Darstellung der Arbeiterklasse. Die darauf folgenden Abschnitte befassen sich mit den Veränderungen in den öffentlichen Äußerungen Bourdieus hinsichtlich der revolutionären Neigungen dieser Menschen. Auf diesem verfänglichen Untersuchungsterrain setzte sich Bourdieu kritisch mit den Ideen Germaine Tillions und Frantz Fanons auseinander. Seine Position wird von einem historisch-philologischen Standpunkt aus betrachtet, damit die Texte in ihre zeitlichen und räumlichen Kontexte gestellt, Parallelen bzw. Unterschiede bestimmt und die von solchen Vergleichen gezeitigten Effekte überprüft werden können. Abschließend wird die Reichhaltigkeit und Originalität betont, die Bourdieus Untersuchungen im Vergleich zu anderen Texten der Zeit auszeichnet, und es werden, mit Blick auf die jüngere globale Neuausrichtung der Geschichte der Arbeit, einige der wesentlichen Perspektiven Bourdieus auf die Ursprünge des Kapitalismus in der Kolonie hervorgehoben.

Übersetzung: Max Henninger 
Andrea Rapini. ¿Pueden los campesinos hacer una revolución? Colonialismo, trabajo y relaciones de poder en los planteamientos de Pierre Bourdieu sobre Argelia.

En este texto se analizan los planteamientos de Pierre Bourdieu sobre Argelia. Comienza por poner recordar las intervenciones más persiasivas a medio y largo plazo del poder colonial francés en la sociedad argelina: la introducción del capitalismo y el internamiento de civiles en los centres de regroupement. A continuación se subrayan los sujetos sociales estudiados por el joven agrégé de Filosofía y su representación de trabajo. Las secciones siguientes tratan de los cambios en la esfera pública de Bourdieu tomando en consideración la propensión revolucionaria de las personas que la componían. En este delicado ámbito de análisis Bourdieu se acabó enfrentando con las ideas defendidas por Germaine Tillion y Frantz Fanon, planteando una confrontación crítica. Su posición se analiza desde una perspectiva histórico-filológica para situar los escritos en sus contextos temporales y espaciales, estableciendo paralelismos y/o divergencias, y comprobando los efectos que resultan de tales comparaciones. Las conclusiones permiten enfatizar la riqueza y originalidad de los planteamientos de Bourdieu para una época en la que estos fueron hechos y pone de relieve, a la luz de la reciente reorientación global de historia del trabajo, alguno de los puntos de vista vitales expresados sobre los orígenes del capitalismo en la colonia. 